\title{
The Origin of Gas Seeps in the Northern Adriatic Sea
}

\author{
Federica Donda (1), Umberta Tinivella (1), Emiliano Gordini (1), Giuliana Panieri (3), Valentina Volpi (1), \\ Dario Civile (1), Edy Forlin (1), Lorenzo Facchin (1), Mihai Burca (1), \\ Andrea Cova (1) \& Giulia M. Ferrante (1)
}

\begin{abstract}
A multidisciplinary approach has been used for the first time to study the widespread occurrence of hydrocarbon seeps in the northern Adriatic Sea. Geological, geophysical and geochemical analyses were performed to identify and characterize the gas-charged fluids occurring throughout the Plio-Quaternary succession, and to date the shallow gas seeping at three leakage sites. The analysis of CHIRP, morpho-bathymetric and multichannel seismic data allowed us to identify different types of gas-related features, which occur within the whole Plio-Quaternary succession up to the seafloor and to the water column. Quantitative analyses of CHIRP data were conducted to better define, characterize and quantify the gas occurrence within the uppermost stratigraphic succession. CHIRP data also allowed identifying the gas leakage sites. Three gas seepage areas were sampled with the aim to determine the gas composition and origin. The isotopic analyses revealed that seep gases are microbial in origin, and are primarily composed by methane, mostly formed within relatively laterally persistent Late Pleistocene peat layers, which are widely distributed throughout the northern Adriatic Sea and represent the main source of organic matter feeding the seeping gases.
\end{abstract}

KEY WORDs: gas seeps, methane, fluid flow in porous media, isotope geochemistry, northern Adriatic Sea.

\section{INTRODUCTION}

Natural gas seeps in marine environments can release considerable amounts of carbon into the water column and the atmosphere (ЕTIOPE, 2012); in some cases, individual seeps can release $\mathrm{CO}_{2}$ and $\mathrm{CH}_{4}$ emissions on the order of tens to hundreds of tons per year (e.g., the Katakolo seep in Greece, the Tommeliten seepage in the North Sea, the seeps off of Panarea Island in the Southern Tyrrhenian Sea; see Eтіоре et alii, 2014 and the references therein). The occurrence of seeps and their distribution are controlled by a number of factors, including the availability of a gas source, the presence of faults and fracture systems, the vertical and lateral changes in sediment properties (i.e., porosity and permeability) and in their depositional history, the sedimentation rates, together with hydrocarbon and methane hydrate exploration (BERNDT, 2005; KESSLER et alii, 2005; CARTWRIGHT, 2007; GAY et alii, 2007; MoERz et alii, 2007; VAN RENSBERgEN et alii, 2007; ANKA et alii, 2012 and references therein; Тотн et alii, 2014; Zнао et alii, 2015; Kramer et alii, 2017).

(1) Istituto Nazionale di Oceanografia e di Geofisica Sperimentale (OGS), Borgo Grotta Gigante 42/c, 34010 Sgonico (Trieste), Italy.

(2) Centre for Arctic Gas Hydrate, Environment and Climate, The Arctic University of Norway, N-9037 Tromsø, Norway.

Corresponding author e-mail: fdonda@inogs.it.
Understanding the mechanisms for natural gas seeps is considerable also because little is still known about the contributions of $\mathrm{CO}_{2}$ and $\mathrm{CH}_{4}$ from natural emissions into the atmosphere, where they play a major role as greenhouse gases, and whose drastic reduction by 2050 would strongly contribute to limiting warming to $1.5^{\circ} \mathrm{C}$ (RogELJ, SHINDELL, JiANG et alii, 2018); especially in shallow ( $<100 \mathrm{~m})$ marine environments, the potential transfer of gas from sediments into the water column and subsequently into the atmosphere may occur (Етіоре et alii, 2014). In fact, according to McGINNIS et alii (2006), most marine sources of the atmospheric $\mathrm{CH}_{4}$ are located in water depth less than $100 \mathrm{~m}$, as testified by the great amounts of $\mathrm{CH}_{4}$ fluxes in the order of $200 \mu \mathrm{mol} \mathrm{m}{ }^{-2} \mathrm{~d}^{-1}$ recorded in the Black Sea (Schmale et alii, 2005).

In the northern Adriatic Sea, gas seeps are widespread. Both the presence of gas seeps and the occurrence of gasrelated seabed and sub-seabed features have been widely documented (NEWTON \& STEFANON, 1975; STEFANON, 1980; Colantoni et alii, 1998; Conti et alii, 2002; PANIERI, 2006; García-García et alii, 2007; Gordini, 2009; Gordini et alii, 2012; Donda et alii, 2013 and 2015). Multi-resolution geophysical data collected by the National Institute of Oceanography and Applied Geophysics (OGS) in 2009 and 2014 revealed the widespread occurrence of acoustic anomalies associated with the presence of gas in the form of sub-vertical zones interpreted as gas chimneys, through which gas can migrate up to the seafloor (DonDa et alii, 2015). These gas seeps appear to be locally associated with distinct rock outcrops, represented by bio-concretionned carbonate rocks, irregularly distributed on the seafloor, that are commonly named "tegnue" or "trezze". Since the past century, different hypotheses regarding the origin of these lithified deposits have been invoked. Recent geological and geophysical data support two possible genetic models: the first one has been developed for a group of rocky outcrops named "Tegnue di Chioggia", which are interpreted as coralligenous buildups growing along paleo tidal channels (Tosi et alii, 2017); the second model involves the role of the gas seeps, thus leading to interpret such deposits as methane-derived carbonates (GoRDINI, 2009; GoRDINI et alii, 2012; Donda et alii, 2013 and 2015). In fact, the occurrence of both deep and shallow gases throughout the PlioQuaternary succession is well known in the study area. The former are microbial gases occurring within Plioceneto-Pleistocene turbiditic sands, as multiple pools within thin sand beds at approximately 1200-1500 mbsf (CASERO, 2004; Bertello et alii, 2008; Casero \& Bigi, 2013). They have been exploited during the 60's, while no hydrocarbon- 
related activities are currently underway in the study area. Shallow gases permeate the Late Pleistocene and Holocene succession, with gas peaks between 15 and $25 \mathrm{~m}$ below the seafloor (CuRzi et alii, 1997; CURzI et alii, 1998; CALDERONI et alii, 1998; Donda et alii, 2008). The current hypothesis is that gases most likely originate from laterally persistent peat layers, which are widely distributed throughout the northern Adriatic Sea and formed between 16,000 and 24,000 years BP in an alluvial plain environment (GoRDINI, 2009; CoRREGGIARI et alii, 1996; ZECCHIN et alii, 2011) during phases of climate improvements of the last glacial phase (i.e., the Laugerie Interstadial; Zecchin et alii, 2011).

Here, we present the results of a multidisciplinary approach that led us to provide an integrated assessment of gas occurrence in the study area, which represents an excellent natural laboratory to study offshore gas seeps because they are widespread and easily accessible, i.e., they are close to the coast at shallow depths. In particular, quantitative analyses of CHIRP data were performed to determine the presence of gas within the uppermost stratigraphic succession, and geochemical analyses of three leakage areas led to define the origin of the seeping gases.

\section{REGIONAL SETTING}

The northern Adriatic Sea is a shallow-water (mean water depth: $25 \mathrm{~m}$ ) sedimentary basin that is a part of the Padano-Adriatic foreland-foredeep domain, which comprises three orogenic chains, i.e., the northern Apennines, the Southern Alps and the Dinarides. Its present-day configuration is the result of two different tectonic stages: an extensional phase spanning the Mid-Late Jurassic into the Early Cretaceous and a complex Cenozoic compressional phase (FANTONI \& FrANCIOSI, 2010; GHIELmi et alii, 2010). Following the Cenozoic compressional events, the Po Plain and the northern Adriatic areas underwent crustal flexure, giving rise to deep foredeep basins filled with clastic sequences (Royden et alii, 1987). A turbidite succession with a thickness of up to $8 \mathrm{~km}$ was deposited in the Apennine foredeep basin and records four Late Miocene-to-Pleistocene compressional tectonic phases (FAntoni \& Franciosi, 2010; Ghielmi et alii, 2010). The Miocene sequence is mostly composed of hemipelagic deposits belonging to the Gallare Marls, whereas the PlioQuaternary succession is characterized by alternations of sand, clay and silt (DONDA et alii 2013; ZECCHIN et alii, 2017 and references therein). Littoral and shelf sands, clayey sands and sandy clays compose the majority of the surficial sediments of the study area (BRAMBATI et alii, 1988).

The oceanographic setting of the study area is characterized by a microtidal regime dominated by cyclonic circulation that is driven by thermohaline currents (Malanotte Rizzoli \& Bergamasco, 1983; Bondesan et alii, 1995). In the Venice area, the monthly distribution of high tides recorded between 1872 and 2017 shows tides peaks during winter time, with oscillation in the order of 100 $\mathrm{cm}$, but peaks of 140-150 cm also occur (Previsioni delle altezze di marea per il bacino San Marco e delle velocità di corrente per il Canal Porto di Lido - Laguna di Venezia). The frequency of such episodes reaches maximum during Autumn-Winter, when sea-level setup induced by winds blowing from southeast coincides with a low atmospheric pressure (GACIC et alii, 2004 and references therein).

\section{MATERIALS AND METHODS}

Data used in this study were collected on board the R/V OGS Explora in 2009 and 2014 in the framework of the "STENAP" (Seismostratigraphic and Tectonic Evolution of the northern Adriatic in the Plio-Quaternary) and "GANDI" (GAs emissions in the northern ADriatIc Sea) projects. The data set consists of approximately $1300 \mathrm{~km}$ of multichannel seismic lines, CHIRP sub-bottom profiles and swath morpho-bathymetry data (Fig. 1).

The acquisition parameters of the multichannel seismic data and the processing sequence is described in Donda et alii (2015). The seismostratigraphic interpretation has been calibrated with well logs obtained from hydrocarbon exploration boreholes drilled in the study area (Fig. 1), where several gas fields were discovered and exploited. Well data are available through the ViDEPI "Visibility of Petroleum Exploration Data in Italy" database (http://www. videpi.com); it consists in a huge data set comprising well and seismic data, in conjunction with technical reports concerning exploration permits collected by oil companies since the 50's.

The CHIRP data were collected through a hull-mounted Chirp Benthos system with 16 transducers and a sweep modulated bandwidth from 2 to $7 \mathrm{kHz}$. The ping rate was set to $0.125-0.25 \mathrm{~s}$ (with a vessel speed of $2 \mathrm{~m} / \mathrm{s}$, which corresponds to one trace per second). The data were stored in a SEGY format, and positioning data from a GPS system was automatically incorporated into the data headers.

Morpho-bathymetry data were collected with a Reson Seabat 8111 multibeam echosounder with a frequency of $100 \mathrm{kHz}$, simultaneously with the seismic and CHIRP data, and were stored and processed within Teledyne RESON's PDS2000 Multibeam software package.

\section{GEOPHYSICAL ANALYSIS OF THE CHIRP DATA}

We performed a quantitative analysis of some key CHIRP profiles in order to constrain the gas occurrence within the uppermost stratigraphic succession. The chosen CHIRP data (see Fig. 2 for location) were acquired from different sectors of the study area; we have selected them based on their sedimentological and acoustic characteristics, i.e., clayey-predominant vs sandy-predominant seafloor (based on BRAMBATI et alii, 1988), acoustic blanking, occurrence of gas flares, presence of a rock outcrop.

Seismic reflection coefficients are related to the acoustic impedance contrasts produced by the different petrophysical properties of sediments in the subsurface. The values of reflection coefficients typically decrease at the interfaces of gas-bearing sediments (TINIVELLA, 2002). In our estimation, we considered two reflecting surfaces, i.e. the seafloor and the gas front, where detectable as a high amplitude reflector on top of the blanking zone. We extracted the reflection coefficient between the seafloor and the gas front by using the method presented by WARNER (1990) and Bull et alii (1998) that is based on the amplitudes of the primary seafloor reflection, the first multiple of the seafloor and the gas front. The reflection coefficients extracted from the CHIRP data were converted into $\mathrm{P}$-wave velocities by using the following available information regarding the seawater and the shallow sediments: seawater - P-wave velocity: $1520 \mathrm{~m} / \mathrm{s}$, density: $1.03 \mathrm{~g} / \mathrm{cm}^{3}$; shallow sediments - grain density: $2.60 \mathrm{~g} /$ 


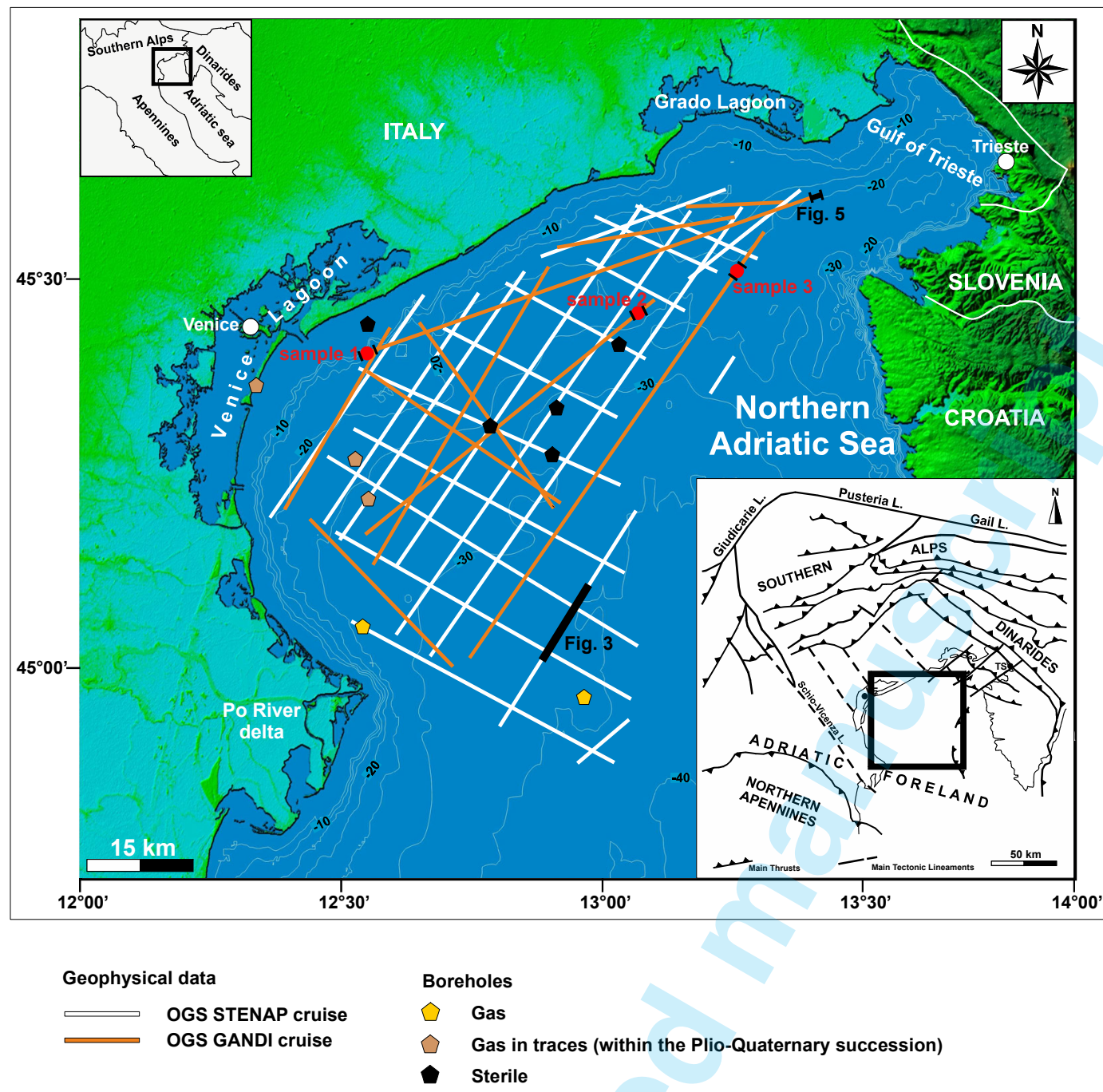

Fig. 1 - Location map of the geophysical data collected by OGS in the framework of the STENAP and GANDI cruises. The position and information concerning the hydrocarbon exploration boreholes is marked, based on the Videpi database (www. videpi.com). The location of the gas sampling sites and of the portions of CHIRP profiles of Fig. 4 (black ticks) are also shown (modified from DonDA et alii, 2015). $\mathrm{cm}^{3}$ (i.e., SchöN, 1996), shallow-sediment porosity (in the selected areas): $38-58 \%$.

The sediment porosity is a parameter needed for the quantitative analyses. The spatial distribution of the surface porosity in the northern Adriatic Sea is shown in Fig. 2, whereas the empty circles indicate the sample location; measurement-related values were achieved from the dbSEABED Colorado database: http://instaar.colorado. edu/ jenkinsc/dbseabed/coverage/adriaticsea/adriatico. htm.

The map was made using DIVA Interpolation (DataInterpolating Variational Analysis): http://modb.oce.ulg. ac.be/mediawiki/index.php/DIVA.

\section{GAS SAMPLING AND ANALYSES}

We have selected the seep sites for gas sampling based on the interpretation of our CHIRP data and the numerous scuba dives performed in the study area in the framework of several research projects (see also GoRDINI, 2009). We have tried to sample the seep sites three times: during the first two dives, seeps were scarce, intermittent and sometimes absent. Then, because gas flares are clearly imaged on the CHIRP data, we hypothesized that tides should have a role in the gas seeps occurrence, as suggested by MikolaJ \& Ampaya (1973) and Boles \& Clark (2011). Variations in seepage due to tidal forcing have been documented in a number of shallow $(<20 \mathrm{~m})$ environments, where pressure changes due to tide oscillations cause 5 to $20 \%$ changes in seepage rates (MikolaJ \& AMPAYA, 1973). We then noticed that, during the first two dives, high tide conditions occurred. Taking into consideration the above mentioned studies, where a straight correlation between high tides and reduced flows, and between low tides and increased flows is highlighted (BolEs \& CLARK, 2011), we planned the third scuba diving campaign at low tide conditions: the gas was seeping from the seafloor and gas bubbles were clearly identifiable in the water column. Gas samples were then collected in May 2016 from the R/V Castorino II, using a self-built device for the fluid accumulation and its transfer into suitable containers. The conveyor device consists of a funnel having a base of 0.1 square meters $(0.35 \mathrm{~m}$ of diameter), mounted on a ballasted steel support that allows to distance the funnel of about 0.15 meters from the surface on which it is placed. Two divers placed the funnel conveyor/accumulator just above the selected gas seeps. After about 30/60 minutes, the gas accumulated in the funnel was removed and subsequently stored inside glass vacuum vials ( $250 \mathrm{ml}$ of volume). 


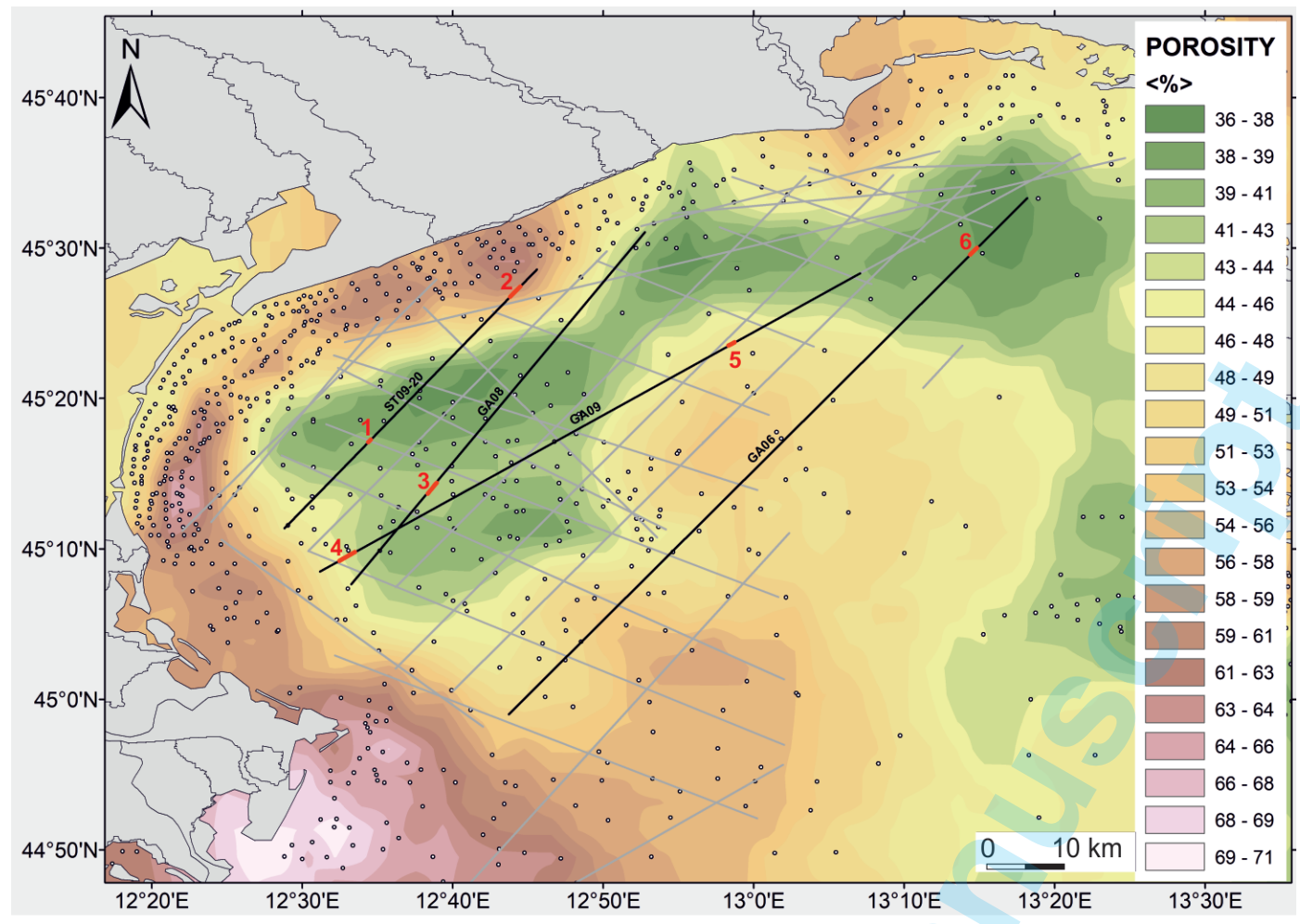

1 ST09-20 part I 2 ST09-20 part II 3 GA08 4 GA09 part I 5 GA09 part II 6 GA06
Fig. 2 - Spatial distribution of the surface sediment porosity throughout the northern Adriatic Sea (see text for details). Red ticks indicate the portions of the selected CHIRP profiles where the quantitative analyses have been performed (see also Table 1), whereas the empty circles indicate the sample location; measurement-related values were achieved from the dbSEABED Colorado database.
The gas samples were analyzed at Isotech Laboratories Inc. (Illinois, USA) to determine the proportions of $\mathrm{C}_{1}-\mathrm{C}_{6}+$ hydrocarbons, $\mathrm{He}, \mathrm{H}_{2}, \mathrm{O}_{2}, \mathrm{Ar}, \mathrm{CO}_{2}, \mathrm{CO}$, and $\mathrm{N}_{2}$ (Shimadzu 2010 Gas Chromatograph (GC) with thermal conductivity (TCD) and flame ionization (FID) detectors; accuracy/precision $+/-5 \%(\mathrm{C} 1-\mathrm{C} 4)$ and $\left.+/-10 \%\left(\mathrm{C}_{5}-\mathrm{C}_{6}+\right)\right)$ and the isotopic compositions of $\mathrm{d}^{13} \mathrm{C}_{\mathrm{CH} 4}$ (Finnigan Delta Plus XL mass spectrometer, accuracy/precision \pm $0.1 \%$ o $(1 \mathrm{~s})$ for ${ }^{13} \mathrm{C}$ ) and $\mathrm{dD}_{\mathrm{CH} 4}$ (Finnigan Delta V Plus mass spectrometer, accuracy/precision $+/-4.0 \%$ ( $1 \mathrm{~s})$ for $2 \mathrm{H})$. The gas samples were outsourced to Beta Analytic (Florida, USA) for the radiocarbon analysis of $\mathrm{CH}_{4}$ via accelerator mass spectrometry. The ${ }^{14} \mathrm{C} 1 \mathrm{pMC}$ were converted into apparent age through the following equation: Age $=-8034$ ln $(\mathrm{pMC})+37000$, which provides an apparent age of ca. 32,000 to 34,000 yrs BP.

\section{RESULTS}

The occurrence of both deep and shallow gases is clearly imaged on the OGS dataset. On the multichannel seismic profiles, as also evidenced by Donde et alii (2013 and 2015), widespread acoustically wipe-out zones (LøSETH et alii, 2009), interpreted as focused fluid flow pipes (HuUse et alii, 2010), indicate gas migration along subvertical pathways (Fig. 3). Gas chimneys commonly root at the base of the Pliocene succession and affect the whole Plio-Quaternary stratigraphic sequence; they are also locally associated with Cenozoic sub-vertical faults. High amplitude reflections at the chimney top (bright spots) are also often recognizable and are interpreted as due to local accumulations of upward migrating gas (Fig. 3).

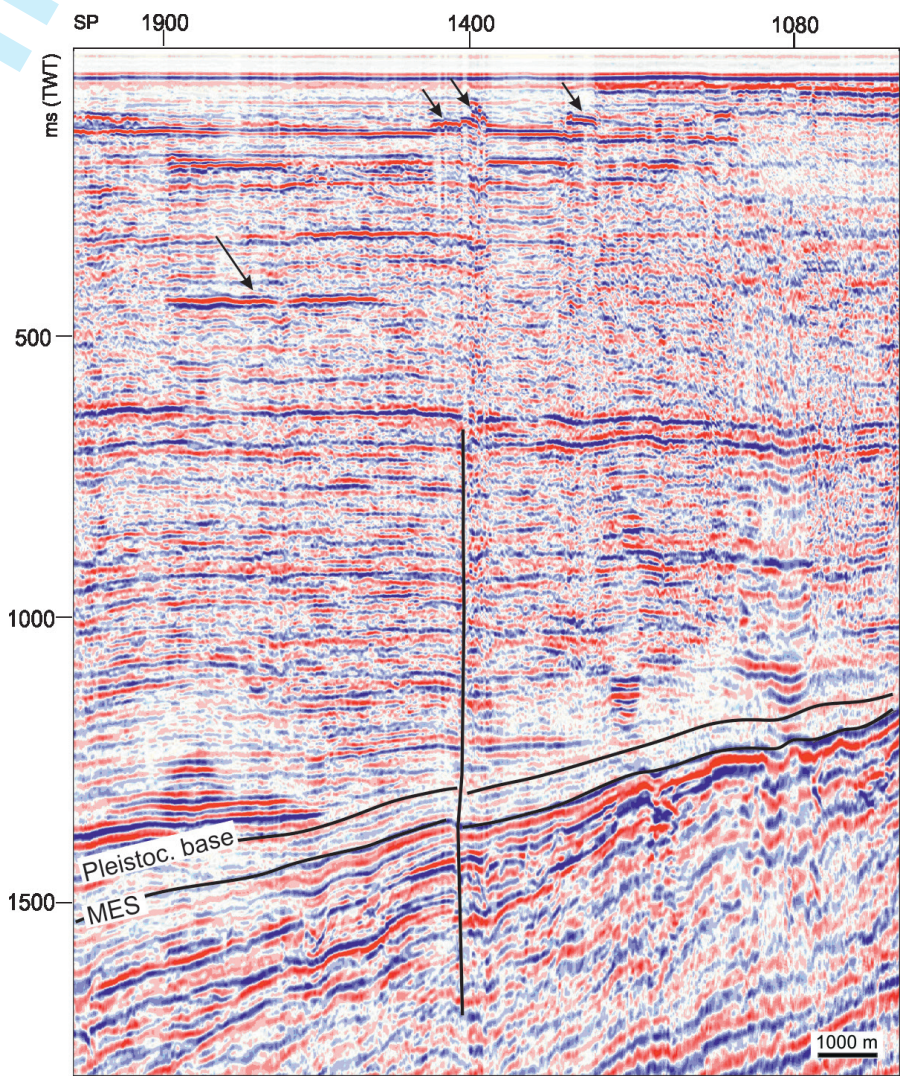

Fig. 3 - Part of the ST09-11b multichannel seismic profile (see Fig. 1 for location). Arrows indicate high amplitude reflections (bright spots), revealing the occurrence of local gas accumulations. A focused fluid flow pipe is recognizable just above of the subvertical fault affecting the Miocene-Pleistocene succession. MES: Messinian Erosional Surface. 
On the CHIRP data, we observe diffuse acoustic blanking, which almost completely masks underlying reflections in the stratigraphic succession. The acoustic blanking is bounded at the top by a high amplitude, sub-horizontal to highly irregular acoustic reflection that represents the gas front (Fig. 4). Truncated reflections at the gas front indicate that gas-trapping horizons are not continuous. Focused acoustic blanking also occurs, i.e., gas chimney-like features (Fig. 4) that, in places, reach the seafloor. In the northernmost sector of the study area, we have identified pockmarks either on CHIRP profiles and at the coincident multibeam data; they display a maximum width and depth of $15 \mathrm{~m}$ and $50 \mathrm{~cm}$, respectively (Fig. 5). Rock outcrops are recognizable on the CHIRP data as rugged seafloor morphologies, acoustically opaque and up-bounded by a high amplitude reflection, with maximum elevations above the seafloor of ca $1 \mathrm{~m}$ (Fig. 4; they and reveal a wide range of sizes, shapes and distributions see also GoRDINI et alii, 2012). The findings of this study support the methane-related origin of at least part of the rock outcrops occurring in the northern Adriatic
Sea, although we do not reject the hypothesis of Tosi et alii (2017) for the Tegnue di Chioggia outcrops, where, in fact, no gas seeps have been detected.

For a comprehensive description of these features, see Gordini (2009), Gordini et alii (2012), Donda et alii (2015), and Tosi et alii (2017) (Fig. 4). Several seep areas are recognizable on the CHIRP data. Based on the acoustic data, gas flares have variable heights that range from $4 \mathrm{~m}$ to approximately $20 \mathrm{~m}$ (Figs. 4 and 5). Flares occur along the water column just above focused fluid migration pathways, in areas of diffuse acoustic blanking and at rock outcrops.

To better constrain the data interpretation, we have then focused our analysis to the uppermost stratigraphic section through a quantitative analysis of key portions of CHIRP data.

In a first instance, knowing the acoustic impedance values of the sediments below the seafloor, we estimated the impedance contrast, and thus, the P-wave velocity at the top of the free gas layer. This allowed us to provide indications regarding the free gas content by using a

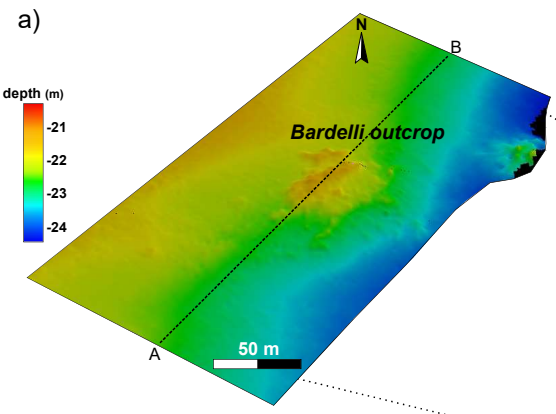

b)

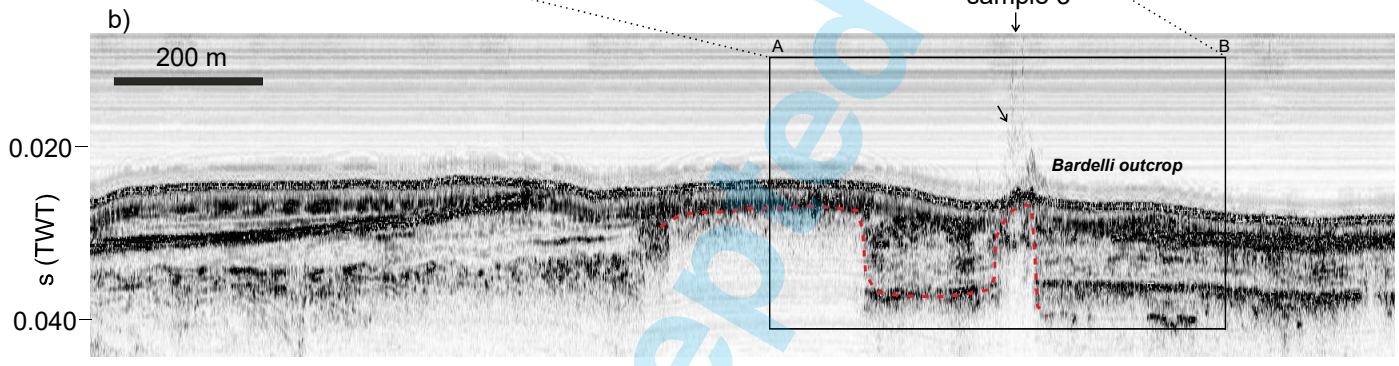

c)

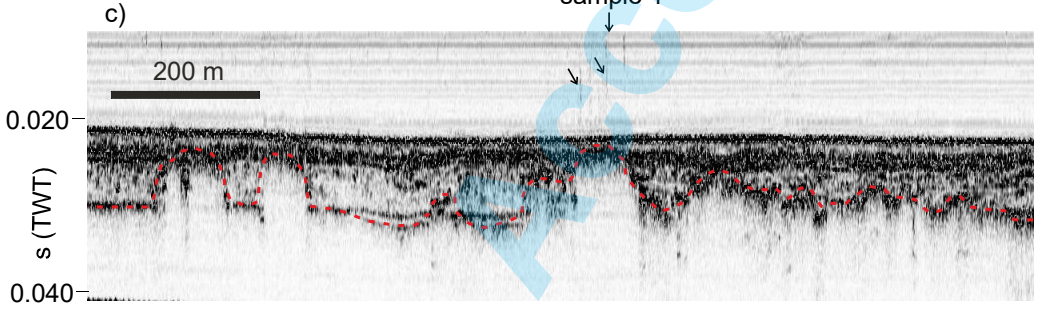

d)

sample 2

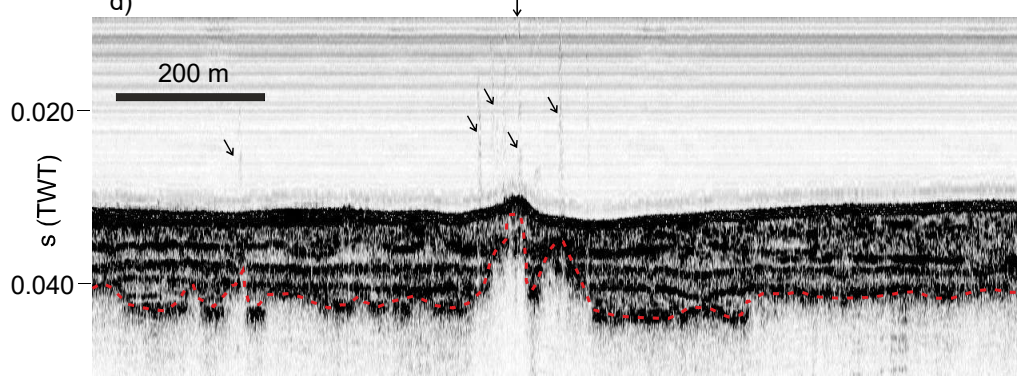

Fig. 4-Parts of GA 06 multibeam data (a) and of the coincident CHIRP profile (b) collected across the Bardelli outcrop, and of GA01 (c) and GA09 (d) CHIRP profiles collected on the leakage areas where the gas have been sampled (see Fig. 1 for location). The dotted red line represents the gas front. Arrows indicate gas flares in the water column. The quantitative analyses resumed in Fig. 8 have been performed on the same portion of GA06 profile shown here. 


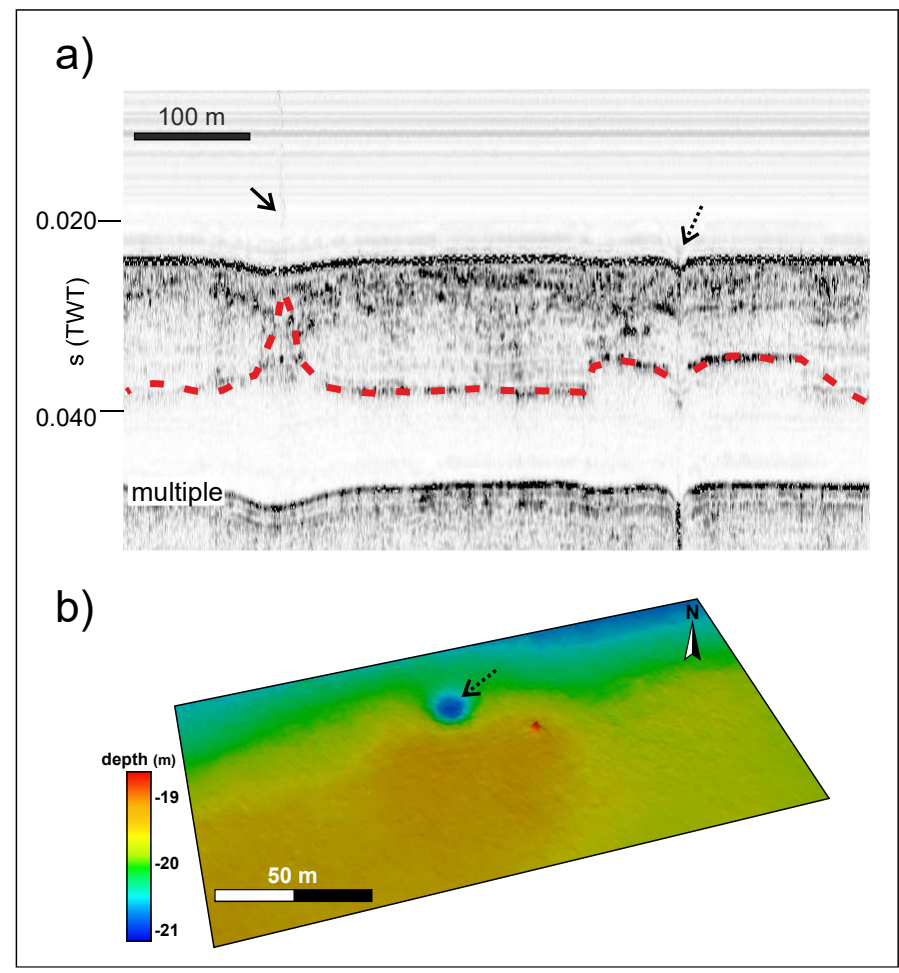

Fig. 5 - Part of GA01 CHIRP profile (a) and of the corresponding multibeam bathymetry data (b) collected in the northernmost sector of the study area (see Fig. 1 for location), where pockmarks have been identified (dotted arrows). The gas front and gas flares in the water column are also indicated by the red dotted line and by the arrow, respectively (Fig. 5a)

theoretical velocity model. Where possible, we selected a reflector between the seafloor and the top of the free gas layer to better constrain the amplitude and the extracted velocities. We used Biot's theory and its approximation in order to convert the velocity into an estimate of the free gas content (i.e., Tinivella \& CARcione, 2001). Figure 6 shows an example of the behaviour of the compressional velocity versus the free gas saturation under the assumption that the water depth is $20 \mathrm{~m}$ (the average value extracted from the bathymetry data), the top of the free gas layer is $5 \mathrm{~m}$ below the seafloor (average value of the gas front depth based on the analysed CHIRP data), and the porosity ranges from 0.38 (dashed lines) to 0.58 (dotted lines).

We assumed two distributions of the free gas within the pore space, namely, a patchy (gray lines in Fig. 6) and a uniform distribution (black lines in Fig. 6). As expected, if we consider a patchy distribution, the velocity is higher relative to the velocity obtained considering a uniform distribution (i.e., Tinivella, 2002). The amplitude of the reflection interpreted as the top of the free gas layer is expected to be negative due to the velocity decrease resulting from the presence of gas. Fig. 6 shows that, if the porosity is equal to 0.58 , the velocity is slightly smaller than that obtained by assuming a porosity of 0.38 in the case of a uniform distribution, while the velocity is constant for a patchy distribution. The relationship between the theoretical absolute reflection coefficient and the free gas saturation, which is evaluated using a viscoelastic singlephase constitutive model (i.e., CARCIONE \& Tinivella, 2000 and 2001), is shown in Fig. 7.

Only the absolute value of the reflection coefficient is reported, because CHIRP data represents an amplitude envelope without phase information. These results, which are consistent with the velocity behaviour, indicate a drop in the reflection coefficient with a small concentration of free gas that is more pronounced if a uniform distribution is assumed. Supposing an increasingly high free gas content (with free gas on the order of approximately $10 \%$ and $20 \%$ in the pore space with a uniform and patchy distribution, respectively), the absolute value of the reflection coefficient strongly increases, thereby producing an ambiguity if only the reflection coefficient value is interpreted; thus, other information, such as geological data, are necessary to constrain the interpretation. For example, for a patchy distribution, an absolute value of the reflection coefficient equal to 0.2 can be interpreted as indicative of the presence of up to approximately $20 \%$ of free gas in the pore space.

The mean values of the reflection coefficient and $\mathrm{P}$-wave velocity are reported in Table 1.

The sampled gases are mainly composed of methane (Table 2). The methane $\delta^{13} \mathrm{C}$ values range between -73.7 and $-64.7 \%$ VPDB, while the $\delta \mathrm{D}$ values range from -264.2 to $-223.6 \%$ VSMOW. The ${ }^{14} \mathrm{C} 1 \mathrm{pMC}$ values range from

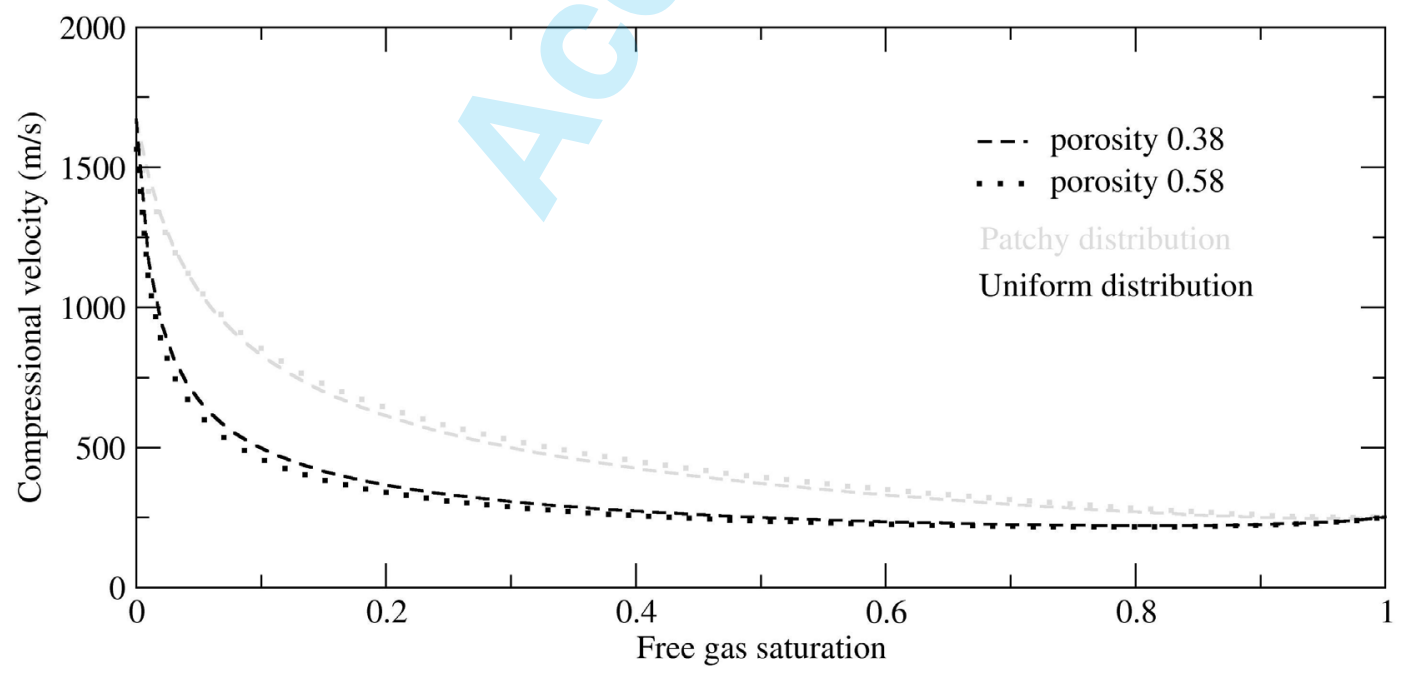

Fig. 6 - Compressional velocity versus free gas saturation, considering different porosity values (0.58: dashed lines; 0.38 : dotted lines) and different distribution of free gas in the pore space (uniform: black lines; patchy: grey lines). See text for details. 


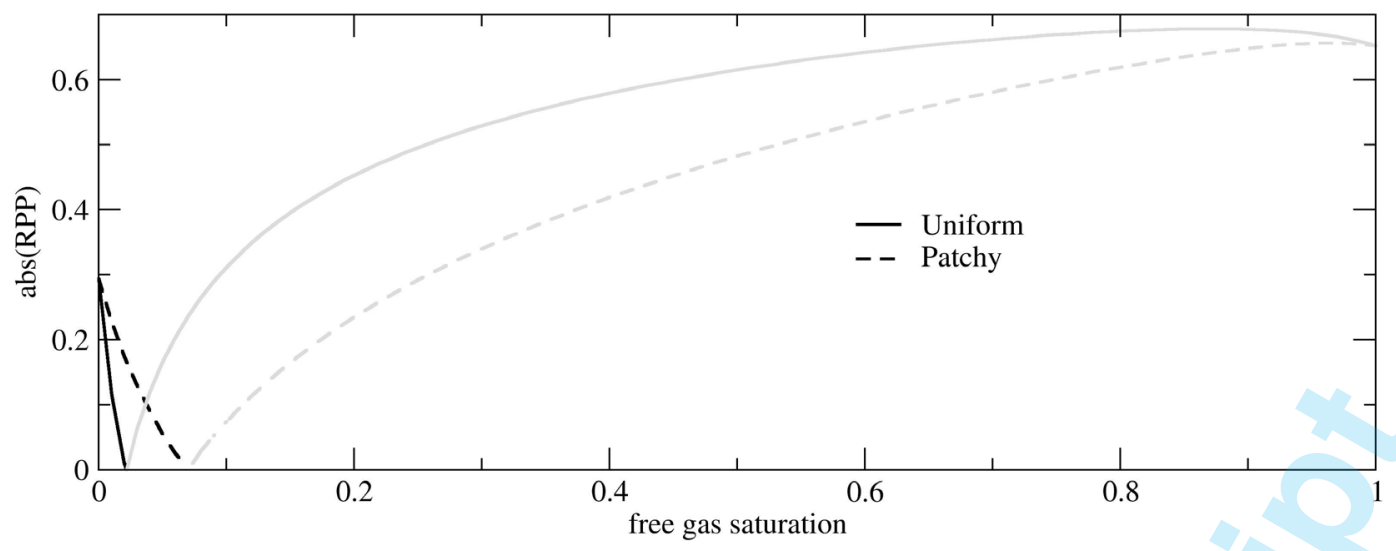

Fig. 7 - Theoretical absolute reflection coefficient versus free gas saturation at the seafloor considering a uniform (solid line) and a patchy (dashed line) free gas distributions in the pore space. The water velocity and the water density are assumed equal to $1.5 \mathrm{~km} / \mathrm{s}$ and to $1.03 \mathrm{~g} / \mathrm{cm}^{3}$, respectively. A sediment density of $2.60 \mathrm{~g} /$ $\mathrm{cm}^{3}$ and a porosity of 0.50 have been considered respectively. Grey lines indicate negative reflection coefficients.
1.3 to 1.8 , which indicates an apparent age of the organic material source for the microbial gas between ca. 32,000 to 34,000 yrs BP. The real age of the source organic material is equal to or less than the apparent age.

\section{DISCUSSION}

\section{Quantitative analysis ON THE CHIRP DATA}

An example of CHIRP data analysis performed on the GA 06 profile is shown in Fig. 8.
We estimated the $\mathrm{P}$-wave velocity from reflection coefficient by using a layer stripping approach. In fact, knowing the reflection coefficient at the interface and the impedance of the upper layer, the bottom impedance can be easily evaluated. Knowing the seawater and the shallow sediment properties, the $\mathrm{P}$-wave velocity at the seafloor and the gas front can be extracted from CHIRP data analysis (Fig. 8 B,D). To notice, in our analysis we assume that the free gas in the pore space is not present at the seafloor and the reflection coefficient is positive. In fact, as reported in Fig. 7, if the free gas presence is assumed at the seafloor, high values should result (about $10 \%$ and $25 \%$ if a uniform or

TABLE 1

Results of the CHIRP Data Analysis. The Error Corresponds to the Standard Deviation. The parts of CHIRP data where the analyses have been performed are also shown.

\begin{tabular}{|c|c|c|c|c|c|c|}
\hline Acoustic Profile & $\begin{array}{c}\text { Porosity } \\
(\%) / \text { Density }^{2} \\
\left(\mathrm{~g} / \mathrm{cm}^{3}\right)\end{array}$ & $\begin{array}{c}\text { Average reflection } \\
\text { coefficient at the } \\
\text { seafloor }\end{array}$ & $\begin{array}{l}\text { Average reflection } \\
\text { coefficient at the gas } \\
\text { front }\end{array}$ & $\begin{array}{l}\text { Average P-wave } \\
\text { velocity at the } \\
\text { seafloor }(\mathbf{k m} / \mathbf{s})\end{array}$ & $\begin{array}{l}\text { Average P-wave } \\
\text { velocity at the gas } \\
\text { front }(\mathrm{km} / \mathrm{s})\end{array}$ & CHIRP \\
\hline $\begin{array}{l}\text { ST09-20 } \\
\text { (part I) }\end{array}$ & $41 / 1.96$ & $0.30 \pm 0.05$ & 1 & $1.5 \pm 0.2$ & 1 & $\left.\begin{array}{l} \\
0 \\
0 \\
\vdots \\
0 \\
0\end{array}\right)$ \\
\hline
\end{tabular}

\begin{tabular}{|c|c|c|c|c|c|c|}
\hline GA 08 & $42 / 1.94$ & $0.27 \pm 0.08$ & I & $1.5 \pm 0.3$ & 1 & 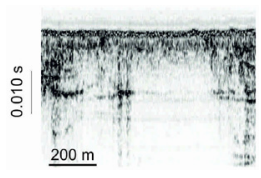 \\
\hline
\end{tabular}

\begin{tabular}{|c|c|c|c|c|c|c|}
\hline $\begin{array}{l}\text { GA09 } \\
\text { (part I) }\end{array}$ & $44 / 1.91$ & $0.28 \pm 0.09$ & I & $1.5 \pm 0.3$ & I & $\begin{array}{l}\text { 200 m } \\
0 \\
\vdots \\
0\end{array}$ \\
\hline $\begin{array}{l}\text { GA } 09 \\
\text { (part II) }\end{array}$ & $48 / 1.84$ & $0.28 \pm 0.06$ & I & $1.5 \pm 0.2$ & I & 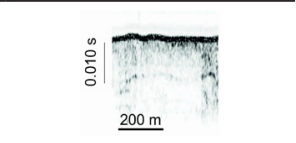 \\
\hline $\begin{array}{l}\text { ST09-20 } \\
\text { (part II) }\end{array}$ & $58 / 1.69$ & $0.28 \pm 0.08$ & $-0.04 \pm 0.03$ & $1.7 \pm 0.3$ & $1.4 \pm 0.1$ & 200m \\
\hline GA 06 & $38 / 2.00$ & $0.37 \pm 0.11$ & $-0.07 \pm 0.08$ & $1.8 \pm 0.5$ & $1.5 \pm 0.3$ & 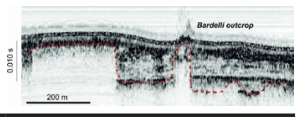 \\
\hline
\end{tabular}


TABLE 2

Molecular and Isotopic Composition of the Gases Sampled at Three Leakage Sites (see Fig. 1 for location).

\begin{tabular}{|c|c|c|c|c|c|c|c|c|c|c|c|c|c|c|}
\hline SAMPLE 1 & $\begin{array}{l}\text { Chemical } \\
\text { mol. } \%\end{array}$ & $\begin{array}{l}\mathrm{d} 13 \\
(\% o)\end{array}$ & $\begin{array}{l}\mathrm{dD} \\
(\% \circ)\end{array}$ & $\begin{array}{l}14 \mathrm{C} \\
\text { conc. } \\
\text { (pMC) }\end{array}$ & SAMPLE 2 & $\begin{array}{l}\text { Chemical } \\
\text { mol. } \%\end{array}$ & $\begin{array}{l}\mathrm{d} 13 \\
(\% o)\end{array}$ & $\begin{array}{l}\mathrm{dD} \\
(\% \circ)\end{array}$ & $\begin{array}{l}14 \mathrm{C} \\
\text { conc. } \\
\text { (pMC) }\end{array}$ & SAMPLE 3 & $\begin{array}{l}\text { Chemical } \\
\text { mol. } \%\end{array}$ & $\begin{array}{l}\mathrm{d} 13 \\
(\% o)\end{array}$ & $\begin{array}{l}\mathrm{dD} \\
(\% \circ)\end{array}$ & $\begin{array}{l}14 C \\
\text { conc. } \\
\text { (pMC) }\end{array}$ \\
\hline $\begin{array}{l}\text { Carbon } \\
\text { Monoxide }\end{array}$ & nd & & & & $\begin{array}{l}\text { Carbon } \\
\text { Monoxide }\end{array}$ & nd & & & & $\begin{array}{l}\text { Carbon } \\
\text { Monoxide }\end{array}$ & nd & & & \\
\hline Helium & nd & & & & Helium & nd & & & & Helium & nd & & & \\
\hline Hydrogen & nd & & & & Hydrogen & nd & & & & Hydrogen & nd & & & \\
\hline Argon & 0.431 & & & & Argon & 0.0970 & & & & Argon & 0.415 & & & \\
\hline Oxygen & 9.70 & & & & Oxygen & 0.98 & & & & Oxygen & 7.67 & & & \\
\hline Nitrogen & 35.92 & & & & Nitrogen & 8.95 & & & & Nitrogen & 31.36 & & & \\
\hline $\begin{array}{l}\text { Carbon } \\
\text { Dioxide }\end{array}$ & 0.99 & & & & $\begin{array}{l}\text { Carbon } \\
\text { Dioxide }\end{array}$ & 0.40 & & & & $\begin{array}{l}\text { Carbon } \\
\text { Dioxide }\end{array}$ & 0.049 & & & \\
\hline Methane & 52.96 & -64.75 & -264.2 & $1.3 \pm 0.1$ & Methane & 89.57 & -73.69 & -237.6 & $1.8 \pm 0.1$ & Methane & 60.50 & -76.22 & -223.6 & $1.8 \pm 0.1$ \\
\hline Ethane & 0.0003 & & & & Ethane & 0.0021 & & & & Ethane & 0.0011 & & & \\
\hline Ethylene & nd & & & & Ethylene & nd & & & & Ethylene & nd & & & \\
\hline Propane & nd & & & & Propane & nd & & & & Propane & nd & & & \\
\hline Propylene & nd & & & & Propylene & nd & & & & Propylene & nd & & & \\
\hline Iso-butane & nd & & & & Iso-butane & nd & & & 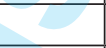 & Iso-butane & nd & & & \\
\hline N-butane & nd & & & & N-butane & nd & & & & N-butane & nd & & & \\
\hline Iso-pentane & nd & & & & Iso-pentane & nd & & & & Iso-pentane & nd & & & \\
\hline N-pentane & nd & & & & N-pentane & nd & & & & N-pentane & nd & & & \\
\hline Hexanes+ & 0.0003 & & & & Hexanes+ & nd & & & & Hexanes+ & nd & & & \\
\hline
\end{tabular}

patchy distribution is assumed respectively), contrary to the gas concentration estimated in this area, which are in order of a few percent (GARCíA-GARCíA et alii, 2007). So, we draw the conclusion that local high values of the reflection coefficients of the seafloor should be associated to lithological changes, as confirmed by the absence of reversal phases along the corresponding seismic lines, i.e. absence of evidence of negative reflection coefficient at the seafloor (i.e., Fig. 8F). Therefore, we suggest that the diffuse acoustic blanking observed below the seafloor is associated with coarsergrained sediments (sand and coarse sand in the case of GA08, GA09-part I and ST20-part I) and/or relatively compacted sediments relative to adjacent areas (GA09-part II). These properties would serve to absorb the energy of seismic signals, thereby resulting in the observed acoustic blanking.

We conducted the same analyses in the sectors where gas flares in the water column confirmed the presence of active gas emissions (Fig. 4). This is the case for profiles ST020-part II and GA06, where the reflection coefficient and velocity were computed at the seafloor and at the potential gas front (Fig. 4; Table 1). The low reflection coefficient and acoustic velocity values at the latter reflector confirm the presence of gas within the sediments with an estimated mean volume concentration on the order of a few percent based on the velocity data reported in Table 1 . These values agree with gas analyses performed on sediment cores collected in the southern portion of the study area, which reveal gas concentrations of at least $1-2 \%$ within the muddominated Holocene highstand system tract (GARCíA-GARCÍA et alii, 2007). The occurrence of gas is represented within our CHIRP data by diffuse acoustic blanking bounded on the top by a high amplitude reflector (Fig. 4). The highest reflection coefficient values at the seafloor in profile GA06 are associated with a rock outcrop.

\section{GAS ANALYSIS}

CHIRP data show the occurrence of widespread gas escapes into the water column in the form of numerous gas bubble streams, which are imaged as 'acoustic flares' on echograms (GoRdInI, 2009; Donda et alii, 2013 and 2015). However, only a few gas samples have been collected and analyzed, the results of which revealed that the gases are mainly composed of methane $\left(\mathrm{CH}_{4}\right.$ : 81-84\%; N : 15-18\%; O : 0.7-1.3\%; GoRdINI, 2009; GordINI et alii, 2012). Further measurements where performed in the northernmost portion of the Adriatic Sea, i.e. the Gulf of Trieste, which was selected as a testing site for the implementation of techniques to monitor submarine gas fluxes and their ecological impacts in the framework of the European $\mathrm{CO} 2 \mathrm{GeoNet}$ project. A data record spanning approximately one year revealed the occurrence of both $\mathrm{CH}_{4}$ and $\mathrm{CO}_{2}$ at low concentrations, i.e. ca $0.2 \%$ and $0.5 \%$, respectively (FABER et alii, 2009). Except for these localized measurements, a whole characterisation of the gas seeps in the northern Adriatic Sea was still missing. In our samples, we discovered several pieces of evidence for the microbial origin of the methane: 1) the ratios of methane to ethane and propane $(\mathrm{C} 1 /(\mathrm{C} 2+\mathrm{C} 3))>1000$ (BERNARD et alii, 1976); 2) the $\delta^{13} \mathrm{C}-\mathrm{CH}_{4}$ values were generally less than approximately $-55 \%$, which is expected for biogenic gases (BERNARD et alii, 1976; WhITICAR et alii, 1986; WhITICAR, 1999); and 3) the stable carbon and hydrogen isotope compositions of methane plotted in the field of biogenic gas (WHITICAR, 1999; Fig. 9). These characteristics argue for a microbial origin through $\mathrm{CO}_{2}$ reduction, which is the main primary methanogenic pathway in marine sediments (CLAYPOOL \& Kvenvolden, 1983; WhiticaR, 1999).

The near absence of hydrocarbons with densities greater than methane $\left(\mathrm{C}_{2}-\mathrm{C}_{6}\right)$ from the gas composition 

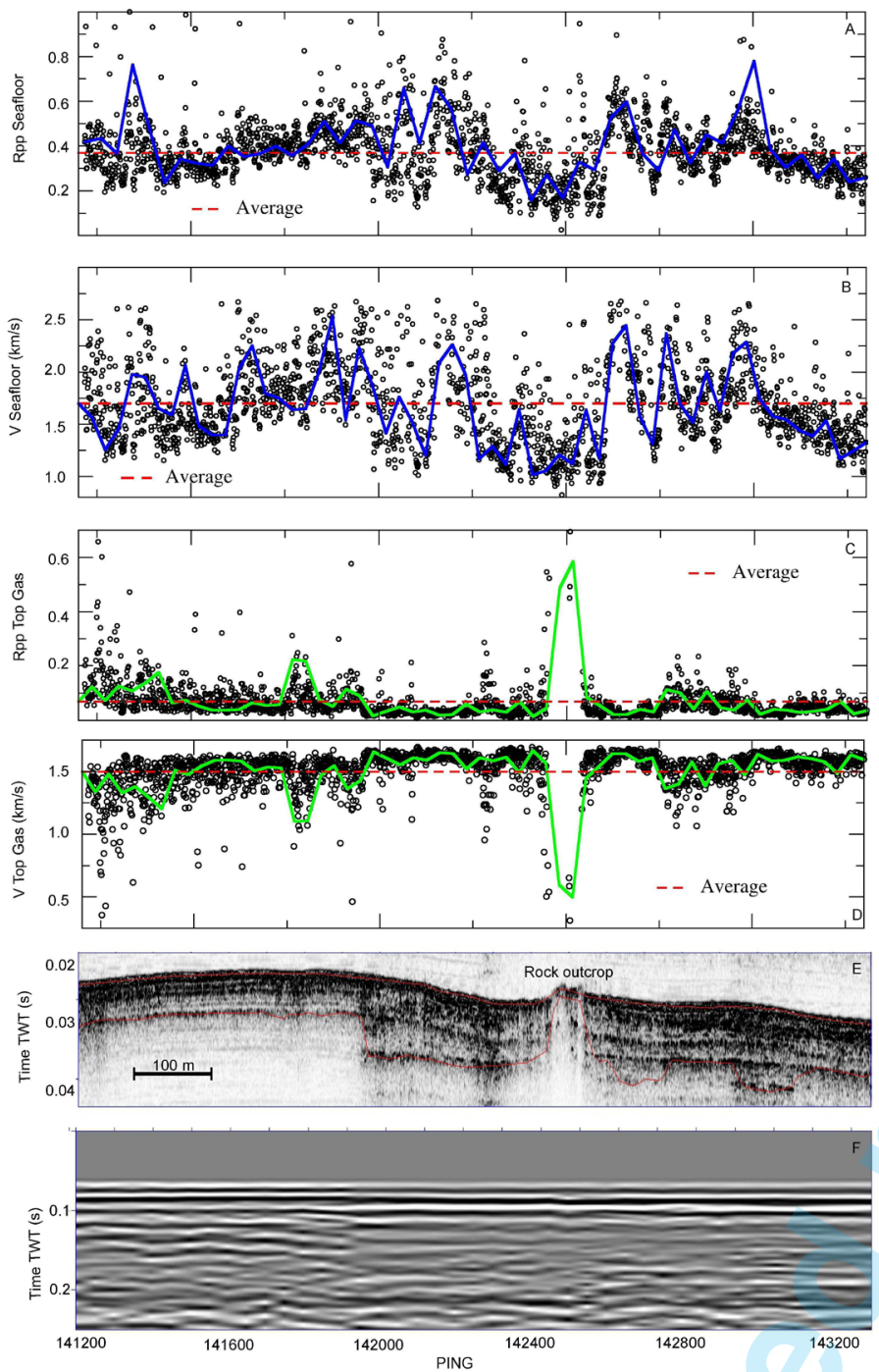

Fig. 8 - CHIRP data analysis performed on the GA 06 CHIRP profile (see Figure 2 for location). Black circles: picked events; blue line: envelope; red dotted line: average of picked events. A. Reflection coefficient of the seafloor; B. P-wave velocity of the seafloor extracted from the reflection coefficients; C. Absolute reflection coefficients of the gas front; green line: envelope; D. P-wave velocity of the gas front extracted from the reflection coefficients; E. portion of the CHIRP profile with the picked reflections, i.e. seafloor and gas front (red lines); F. coincident portion of the near offset multichannel seismic profile.

in addition to the observed stable isotopes and the age of the organic source material for the methane collectively support a relatively shallow primary microbial methane source (SCHOELL, 1980; WhITICAR et alii, 1986).

\section{ORIGIN OF THE GAS SEEPS}

Different types of gas-related features are recognizable within the whole Plio-Quaternary succession in the northern Adriatic Sea (Fig. 10), and we hypothesize two main sources feeding the shallow gas accumulations and the gas seeps (Fig. 11). The deeper one is evidenced on the multichannel seismic data by seismic features such as bright spots and gas chimneys rooting at depths of ca $1 \mathrm{~s}$ (TWT), and by direct evidence of gas occurrence provided by the available composite logs of boreholes

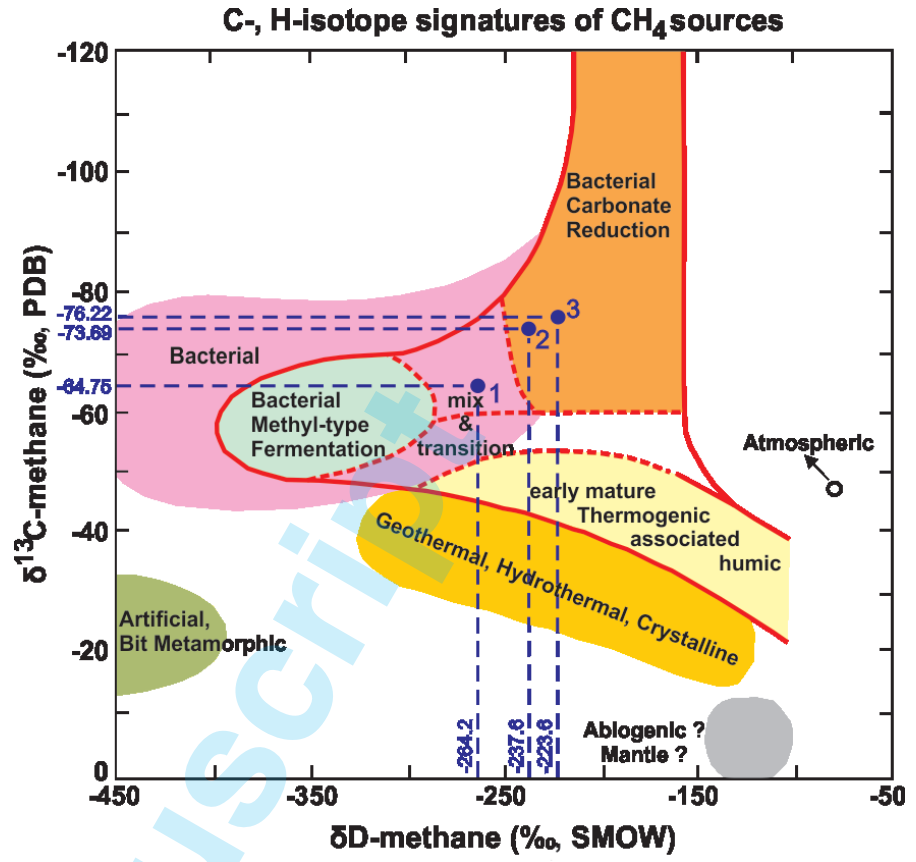

Fig. $9-\delta^{13} \mathrm{CH}_{4}$ vs. $\delta \mathrm{D}-\mathrm{CH}_{4}$ plot showing the major methane types (after Whiticar, 1999, modified). The plotted stable carbon and hydrogen isotope compositions of the gases sampled in the northern Adriatic Sea (indicated as " 1 ", " 2 " and " 3 ") reveal the microbial origin of the methane.

drilled in the study area. No information about the depth of the gas reservoirs are presently available, but the bright spots identified in correspondence of these reservoir, lying at a depth of about $1 \mathrm{~s}$ (TWT), would represent their geophysical expression.

Available data regarding the gas composition of the gas reservoirs reveal the predominance of $\mathrm{CH}_{4}$ (ca 99\%), with the occurrence of $\mathrm{N}_{2}$ and $\mathrm{CO}_{2}$ in the order of $1 \%$ and $0.02 \%$ in vol, respectively (e.g. Panieri, 2006). We suggest that these gases contribute to the shallow gas accumulations, hypothesizing an upward migration of gases through high-permeability layers hosted within the Plio-Quaternary succession and, locally, to sub-vertical faults. Although tectonic stresses appear to be the most efficient triggering mechanism for seeps (TALUKDER, 2012), gases may migrate upward via permeable pathways or they could be driven by buoyancy forces that exceed the threshold pressure of the overburden sediments, according to GARCÍA-GARCÍA et alii (2007).

Only part of the deeper gas would reach the surface, since the characteristics of the uppermost (i.e., $50 \mathrm{~m}$ ) stratigraphic succession, which is dominated by finegrained sediments according to data from the Venezia 1 and Triglia Mare 1 boreholes (www.videpi.com), indicate that it could have acted as a seal for upwardmigrating gases; this is evidenced by the high amplitude reflections at the top of gas chimneys, which record localized, shallow gas accumulations. The acoustic characteristics of the uppermost sedimentary sequence reveal that gas is widely distributed throughout the study area. Isotopes of our gas samples revealed an apparent organic matter age ranging from approximately 32,000 to 34,000 years BP. These ages are consistent with the Denekamp Interstadial, during which time the improved 


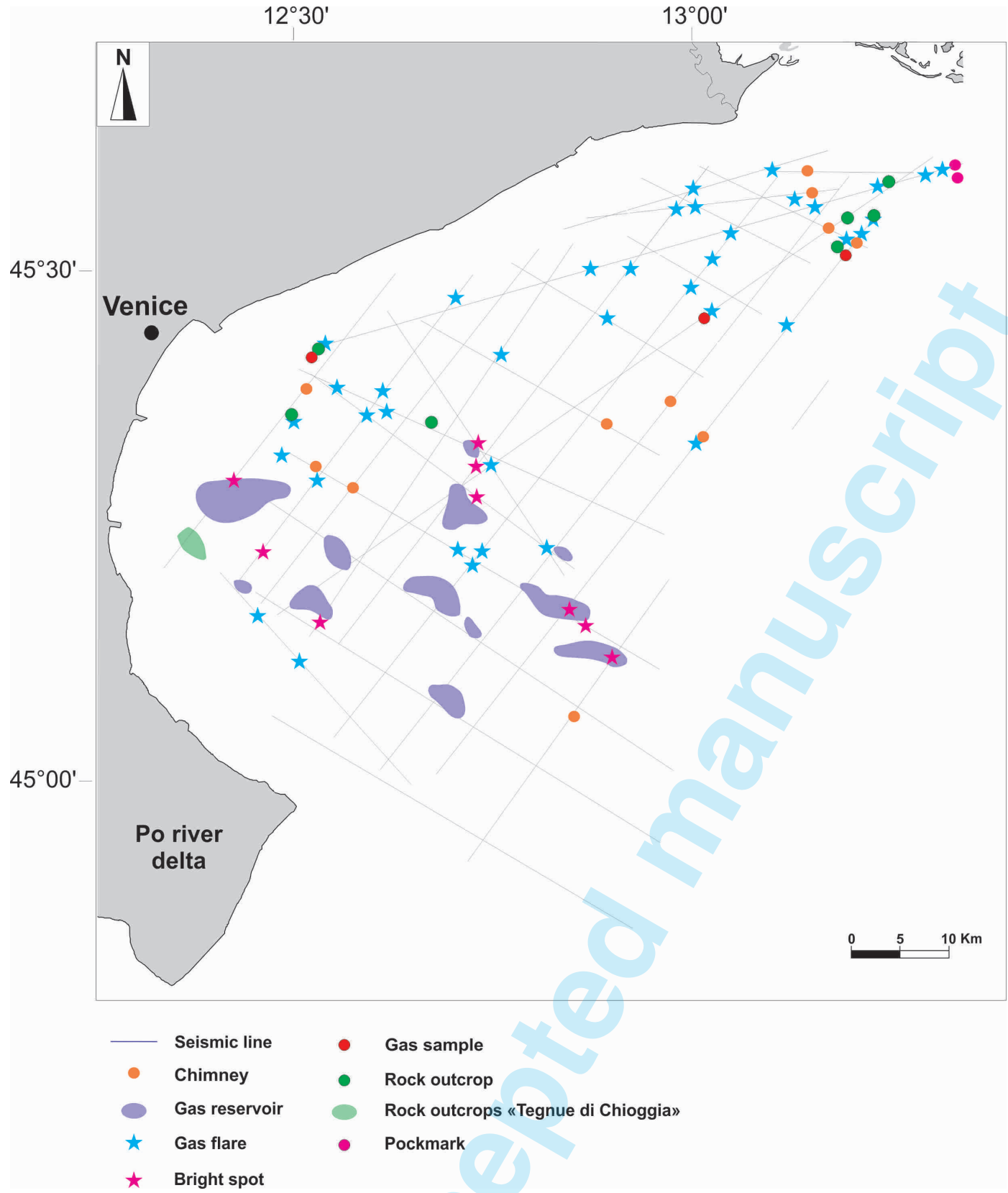

Fig. 10 - Distribution of the gas-related features identified in the study area. The "Tegnue di Chioggia" and the gas reservoirs have been mapped following Tosi et alii (2017) and CASERO (2004), respectively. climate conditions would have favored the deposition of peat layers (CANALI et alii, 2007). We then suggest that the widespread occurrence of shallow gas, identified through both the seismostragraphic and quantitative analyses of the CHIRP data, mostly derives from the Late Pleistocene peat layers, possibly mixed with some gas of deeper origin (Fig. 11).

\section{CONCLUSIONS}

Geological, geophysical and geochemical analyses allowed to identify and characterize the gas-charged fluids occurring throughout the Plio-Quaternary succession, and to date the shallow gas seeping at three leakage sites. In particular:
- Different types of gas-related features have been identified within the whole Plio-Quaternary succession up to the seafloor and to the water column;

- Quantitative analyses of CHIRP data led to the determination of the presence of gas within the uppermost stratigraphic succession, and a definition of its mean volumetric concentration, which is on the order of a few percent.

- Geochemical analyses performed at three leakage areas revealed that seep gases are microbial, and ${ }^{14} \mathrm{C}$ isotopes indicate that they mostly originate from the degradation of organic material with an apparent age of ca. 32,000-34,000 yrs BP. These isotopic signatures suggest the formation of shallow methane within relatively laterally persistent, Late Pleistocene peat layers, which are widely distributed throughout the northern Adriatic Sea. 


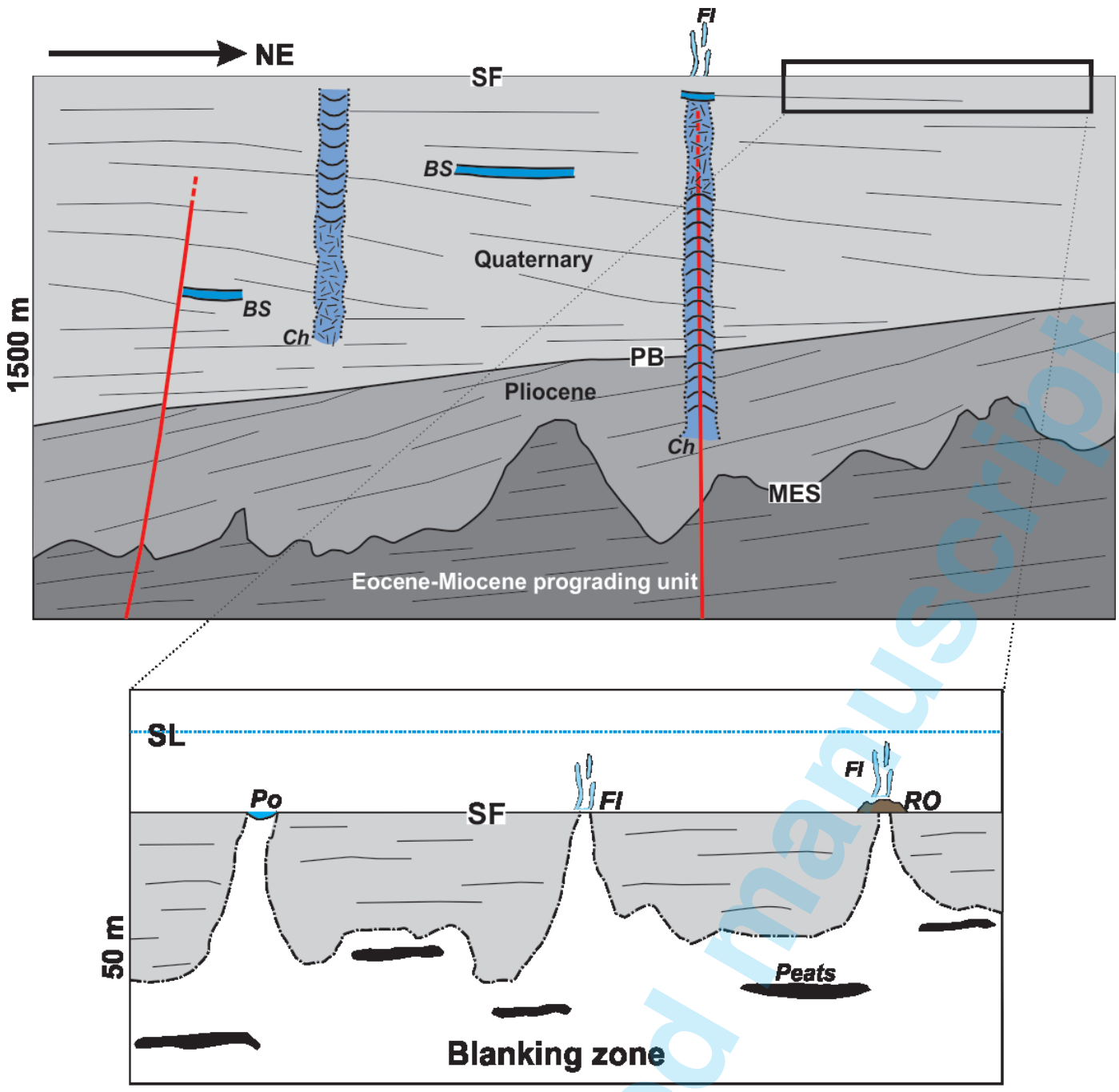

\author{
SF: seafloor \\ SL: sea level \\ BS: bright spot \\ FI: flares \\ Ch: chimney \\ MES: Messinian unconformity \\ Po: pockmark \\ PO: rock outcrop \\ red lines: faults
}

Fig. 11 - The plumbing system model for the northern Adriatic Sea. In the upper panel, two reflector configurations, i.e. pull up and pull down, are identifiable within the chimneys. The up-tilted reflections could be due to sediment deformation induced by upward migration of gas-enriched fluids (e.g. DonDa et alii, 2015) or to localized higher seismic velocities, possibly indicating carbonate cementation within otherwise poorly cemented sediments (e.g. Cowley \& O’Brien, 2000). Pull down reflector configurations would testify to a local decrease of the seismic velocity due to gas occurrence. In the lower panel, the blanking zone reflects the occurrence of gas-charged sediments.

\section{ACKNOWLEDgmenTs}

We thank the crew of the R/V OGS Explora and to the OGS technicians and engineers for their support during the geophysical cruises. We are also grateful to: Dr. S. Caressa, the captain of the R/V Castorino II, and to Dr. S. Ciriaco (Shoreline) for all their efforts to collect the gas samples also in bad weather conditions; Dr. G. Etiope for precious information concerning the gas analyses; Dr. M. Giustiniani and Dr. Lodolo for useful discussions and suggestions on quantitative data analysis and manuscript organization. We are in debt with Dr. A. Judd and Dr. M. Whiticar for valuable discussions and suggestions on the interpretation of geochemical data. We acknowledge Dr. A Gay and an anonymous reviewer, together with the Editor, prof. W. Cavazza and the Associate Editor, Dr. A. Argnani, for the valuable and constructive comments on the manuscript. We thank also IHS Markit Global Sàrl for providing an academic license for KingdomSeismic\&Geological Interpretation Software. Geophysical data are available on request from the corresponding author or via https:// snap.ogs.trieste.it/cache/index.jsp.

\section{REFERENCES}

AnKa Z., Berndt C. \& Gay A. (Eds.) (2012) - Hydrocarbon leakage though focused fluid flow systems in continental margins. Mar. Geol., 332-334,1-3.

Berndt C., Mienert J., Vanneste M. \& Bunz S. (2005) - Gas hydrate dissociation and sea-floor collapse in the wake of the Storegga Slide, Norway Onshore-Offshore Relationships on the North Atlantic Margin. Npf Sp. Publ., 12, 285-292.

Bertello F., FAntoni R. \& Franciosi R. (2008) - Hydrocarbon occurrences in Mesozoic carbonate units in Italy. Rend. Soc. Geol. It., 2, 37-40.

Boles J.R. \& CLARK J.F. (2011) - Temporal variation in natural methane seep rate due to tides, Coal Oil Point area, California. J. Geophys. Res., 106, NO, C11, 27077-27086.

Bondesan M., Castiglioni G. B., Elmi C., Gabbianelli G., Marocco R., Pirazzoli P. A. \& Tomasin A. (1995) - Coastal areas at risk from store surges and sea-level rise in north-eastern Italy. J. Coastal. Res., 11, 1354-1379. 
Brambati A., Ciabatti M., Fanzutti G. P., Marabini F. \& Marocco R. (1988) - Carta sedimentologica dell'Adriatico settentrionale (Sheet 924, scale 1:250,000). Novara, IT: Istituto Geografico De Agostini.

Bull J., QuinN R. \& Dix J. K. (1998) - Reflection coefficient calculation from marine high-resolution seismic reflection (CHIRP) data and application to archeological case study. Mar. Geophys. Res., 20, 1-11.

Calderoni G., Curzi P. V., Paganelli A. \& Sartori E. (1998) - Stratigraphic paleoenvironmental preliminary results of Late Quaternary gassy sediments in Venice Lagoon. Paper presented at 5th International Conference on Gas in Marine Sediments, Bologna, Italy.

Canali G., Capraro L, Donnici S., Rizzetto F., Serandrei-Barbero R. \& Tosi L. (2007) - Vegetational and environmental changes in the eastern Venetian coastal plain (Northern Italy) over the past 80,000 years. Palaeogeogr Palaeocl, 253, 300-316.

Carcione J. M. \& Tinivella U. (2000) - Bottom simulating reflectors: Seismic velocities and AVO effects. Geophysics, 65, 54-67.

Carcione J. M. \& Tinivella U. (2001) - Errata to "Bottom simulating reflectors: Seismic velocities and AVO effects. Geophysics, 78 https://doi:10.1190/1.1444988.

CASERo P. (2004) - Structural setting of petroleum exploration plays in Italy. It. Geol. Soc., special vol. for the 32th International Geological Congress, 20-28 Aug. 2004, Florence, Italy.

CASERo P. \& Bigi S. (2013) - Structural setting of the Adriatic basin and the main related petroleum exploration plays. Mar. Petrol. Geol., 42, 135-147.

CARTWRIGHT J. (2007) - The impact of 3 D seismic data on the understanding of compaction, fluid flow and diagenesis in sedimentary basins. J. Geol. Soc. London., 164, 881-893.

Claypool G. E. \& Kaplan I. R. (1974) - The origin and distribution of methane in marine sediments. In: KAPLAN I.R. (Ed.) Natural Gases in Marine Sediments, Marine Science, 3, 39-139. Plenum, New York, pp. 99-139.

Claypool G. E. \& Kvenvolden K.A. (1983) - Methane and other hydrocarbon gases in marine sediments. Ann. Rev. Earth Pl. Sc., 11, 299-327.

Clennell M. B., Knipe R. J. \& Fisher Q. J. (1998) - Fault zones as barriers to, or conduits for fluid flow in argillaceous formations. a microstructural and petrophysical perspective. In: N.W. Group (Eds.), Fluid flow through faults and fractures in the argillaceous formations (pp. 125-139). Paris, F: Nuclear Energy Agency of the OECD (NEA).

Colantoni P., Gabbianelli G., Ceffa L., Ceccolini C. \& Ricchiuto T. (1998) - Bottom features and gas seepages in the Adriatic Sea. Paper presented at 5th International Conference on Gas in Marine Sediments, Bologna, Italy.

Conti A., Stefanon A. \& Zuppi G. M. (2002) - Gas seeps and rock formation in the northern Adriatic Sea. Cont. Shelf Res., 22, 23332344.

Cordella M., Zampato L., Pastore F., Tomasin A., Canestrelli P. \& Ferla M. (2010) - Le tavole annuali di marea per Venezia. Atti dell'Istituto Veneto di Scienze, Lettere ed Arti, Tomo CLXIX, 43-60.

Correggiari A., Roveri M. \& Trincardi F. (1996) - Late Pleistocene and Holocene evolution on the North Adriatic Sea. Ital. J. of Quat. Sc., 9, 697-704.

COWLEY R. \& O'BRIEN G.W. (2000) - Identification and interpretation of leaking hydrocarbons using seismic data: a comparative montage of examples from the major fields in Australia's north west shelf and Gippsland Basin. The APPEA Journal, 40(1), 121-150.

CURZI P.V. (1998) - Sedimentation, subsidence and tectonics affecting gas charged sediments in the Central Adriatic Sea. Paper presented at 5th International Conference on Gas in Marine Sediments, Bologna, Italy.

CuRzi P.V., Fabiano M. \& FaVa G. (1997) - Gas and organic matter in last glacial and holocenic sediments of Venice lagoon. Chem. Ecol., 14, $1-20$.

Curzi P.V., Danovaro R. \& Bruni R. (1998) - Gas, bacterial biomass and $O M$ composition in marine and continental sediment layers from the Venice Lagoon. Paper presented at 5th International Conference on Gas in Marine Sediments, Bologna, Italy.

Donda F., Civile D., Forlin E., Volpi V., Zecchin M., Gordini E., Merson B. \& De Santis L. (2013) - The northernmost Adriatic Sea: a potential location for $\mathrm{CO}_{2}$ geological storage? Mar. Petrol. Geol., 42, 148-159.
Donda F., Forlin E., Gordini E., Panieri G., Buenz S., Volpi V., Civile D. \& DE SANTIS, L. (2015) - Deep-sourced gas seepage and methanederived carbonates in the Northern Adriatic Sea. Basin Res., 27, 531-545.

Etiope G. (2012) - Methane uncovered. Nat. Geosc., 5, 373-374.

Etiope G., Panieri G., Fattorini D., Regoli F., Vannoli P., italiano F., LOCRITANI M. \& CARMISCIANO C. (2014) - A thermogenic hydrocarbon seep in shallow Adriatic Sea (Italy): Gas origin, sediment contamination and benthic foraminifera. Mar. Petrol. Geol., 57, 283-293.

Faber E., Poggenburg J., Teschner M., Schultz H.-M. \& Moeller I. (2009) - Report on automatic detection of offshore gas releases and CO2 and CH4 concentrations: results of a feasibility study. JRAP-18: Monitoring Near-Surface Leakage and its Impacts, CO2GeoNet.

FANTONI R. \& Franciosi R. (2010) - Tectono-sedimentary setting of the Po Plain and Adriatic foreland. Rend. Lincei-Sci. Fis., 21, 197-209.

Gačić M., Mosouera I.M., Kovačević V., Mazzoldi A., Cardin V., Arena F. \& Gelsi G. (2004) - Temporal variations of water flow between the Venetian lagoon and the open sea. Journal of Marine System, 51, 33-47.

Gay A., Lopez M., Berndt C. \& Séranne M. (2007) - Geological controls on focused fluid flow associated with seafloor seeps in Lower Congo Basin. Mar. Geol., 244, 68-92.

García-García A., Orange D. L., Miserocchi S., Correggiari A., Langone L., Lorenson T.D., Trincardi F. \& Nittrouer C.A. (2007) - What controls the distribution of shallow gas in the Western Adriatic Sea? Cont Shelf Res, 27, 359-374.

Ghielmi M., Minervini M., Nini C., Rogledi S., Rossi M. \& Vignolo A. (2010) - Sedimentary and tectonic evolution in the eastern PoPlain and northern Adriatic Sea area from the Messinian to Middle Pleistocene (Italy). Rend. Lincei-Sci Fis., 21, 131-166.

Gordini E., Marocco R., Tunis G. \& Ramella R. (2004) - The cemented deposits of the Trieste Gulf (Northern Adriatic Sea): areal distribution, geomorphologic characteristics and high resolution seismic survey. Ital. J. Quat. Sc., 17(2/2), 555-563.

GoRDINI E. (2009) - Integrazione di metodologie geofisiche, geomorfologiche, sedimentologiche e geochimiche per la definizione della genesi e dell'età degli affioramenti rocciosi presenti sul fondale marino dell'Adriatico settentrionale, (PhD's thesis). Retrieved from [http://hdl.handle.net/10077/3206]. Trieste, IT: Univ. of Trieste.

Gordini E., Falace A., Kaleb S., Donda F., Marocco R. \& Tunis G. (2012) - Methane-Related Carbonate Cementation of Marine Sediments and Related Macroalgal Coralligenous Assemblages in the Northern Adriatic Sea. In P.T. HARRIS \& E.K. BAKER (Eds.), Seafloor Geomorphology as Benthic Habitats. (pp. 183-198). London, UK: Elsevier.

Hovland M. \& Judd A. G. (1988) - Seabed Pockmarks and Seepages. Impact on geology, Biology and the Marine Environment. London: Graham \& Trotman.

Huuse M., Jackson C.A.-L., Van Rensbergen P., Davies R.J., Fleming P.B., Dixon R.J. (2010) - Subsurface sediment remobilisation and fluid flow in sedimentary basins: an overview. Bas. Res., 22, 342 360.

Kessler J. D., Reeburgh W. S., Southon J. \& Varela (2005) - Fossil methane source dominates Cariaco Basin water column methane geochemistry. Geophys Res Lett, 32, L12609, doi:10.1029/2005GL022984.

Koch S., Berndt C., Bialas J., Haeckel M., Crutchely G., Papenberg C., Klaeschen D. \& Greinert J. (2015) - Gas-controlled seafloor doming. Geology, 43(7), 571-574.

Krämer K., Holler P., Herbst G., Bratek A., Ahmerkamp S., Neumann A., Bartholomä, van Beusekom J.E.E., Holtappels M. \& Winter C. (2017) - Abrupt emergence of a large pockmark field in the German Bight, North Sea. Scientific Report, 7, doi: 10.1038/s41598-01705536-1.

Krooss B. M., Littke R., Mueller B., Frielingsdorf J., Scwochau K. \& IDIz E.F. (1995) - Generation of nitrogen and methane from sedimentary organic matter: implications on the dynamics of natural gas accumulations. Chem. Geol., 126, 291-318.

LøSeth H., Gading M. \& WensaAs L. (2009) - Hydrocarbon leakage interpreted on seismic data. Mar. Petr. Geol., 26, 1304-1319.

Malanotte Rizzoli P. \& Bergamasco A. (1983) - The dynamics of the coastal region of the Northern Adriatic Sea. J. Phys. Oceanogr., 13, 1105-1130. 
Mazzini A., Ivanov M. K., Parnell J., Stadnitskaia A., Cronin B. T., Poludetkina E., Maruzenko L. \& van Weering T.C.E. (2004)Methane-related authigenic carbonates from the Black Sea: geochemical characterisation and relation to seeping fluids. Mar. Geol., 212, 153-181.

McGinnis D.F., Greinert J., Artemov Y., Beaubien S.E. \& Wuest A (2006) - Fate of rising methane bubbles in stratified waters: how much methane reaches the atmosphere? J. Geophys. Res., 111 C09007. doi:10.1029/2005JC003183.

Mikolaj P.G. \& Ampaya J.P. (1973) - Tidal effects on the activity of natural submarine oil seeps. Marine Technical Society Journal, 7, 25-28.

Moerz T., Karlik E. A., Kreiter S. \& Kopf A. (2007) - An experimental setup for fluid venting in unconsolidated sediments: new insights to fluid mechanics and structures. Sediment. Geol., 196, 251-267.

Newton R. \& Stefanon A. (1975) - The "Tegnue de Ciosa" area: patch reefs in the Northern Adriatic Sea. Mar. Geol., 8, 27-33.

Osborne M.J. \& Swarbrick R.E. (1997) - Mechanisms for generating overpressure in sedimentary basins: a reevaluation. AAPG Bull, $\mathbf{8 1}$ 1023-1041.

PANIERI G. (2006) - Foraminiferal response to an active methane seep environment: a case study from the Adriatic Sea. Mar. Micropaleontol., 61, 116-130.

RogelJ J., Shindell D. \& JiAng K. (2018) - Mitigation pathways compatible with $1.5^{\circ} \mathrm{C}$ in the context of sustainable development. In Global Warming of $1.5^{\circ} \mathrm{C}$, Special report of Intergovernmenta Panel of Climate Change (IPCC), Chapter 2.

Royden L., Patacca E. \& Scandone P. (1987) - Segmentation and configuration of subducted lithosphere in Italy: an important control on thrust-belt and foredeep-basin evolution. Geology, 15, 714-717.

Rutherford S. R. \& Williams R. H. (1989) - Amplitude-versus-offset variations in gas sands. Geophysics, 54(6), 680-688. https://doi. org/10.1190/1.1442696.

Schmale O., Greinert J. \& Rehder G. (2005) - Methane emission from high-intensity marine gas seeps in the Black Sea into the atmosphere. Geophys. Res. Lett. 32, L07609. doi:10.1029/2004GL021138.

Schoell M. (1980) - The hydrogen and carbon isotopic composition of methane from natural gases of various origins. Geochim. Cosmochim. Ac., 44, 649-661.

Sснӧм J. H. (1996) - Physical properties of the rocks. Fundamentals and principles of petrophysics. Oxford, OX, UK: Pergamon.

Sibson R. (1981) - A Brief Description of Natural Neighbor Interpolation. In J. Wiley \& Sons (Eds.), Interpreting multivariate data. New York, USA: Wiley.
SteFANON A. (1980) - The acoustic response of some gas-charged sediments in the Northern Adriatic sea. Paper presented at Bottom Interacting Ocean Acoustic Conference, SACLANT ASW Centre, La Spezia, Italy.

TALUKDER A.R. (2012) - Review of submarine cold seep plumbing systems: leakage to seepage and venting. Terra Nova, 24(4), 255-272.

Tinivella U. (2002) - The seismic response to overpressure versus gas hydrate and free gas concentration. J. Seism. Explor., 11, 283-305.

Tinivella U. \& CARcione J.M. (2001) - Estimation of gas-hydrate concentration and free-gas saturation from log and seismic data. The Leading Edge, 20, 200-203.

Tosi L., Zecchin M., Franchi F., Bergamasco A., Da Lio C., Baradello L., Mazzoli C., Montagna P., Taviani M., Tagliapietra D., Carol E. Franceschini G., Giovanardi O. \& Donnici S. (2017) - Paleochannel and beach-bar palimpsest topography as initial substrate for coralligenous buildups offshore Venice, Italy. Scientific Reports, 7, 1321. https:// 10.1038/s41598-017-01483-z.

Toth Z., Spiess V., Mogollon J.M. \& Jensen J. (2014) - Estimating the free gas content in the Baltic Sea sediments using compressional wave velocity from marine seismic data. J Geophys. Res., Solid Earth, 119, 8577-8593, doi:10.1002/2014JB010989.

Van Rensbergen P., Rabaute A., Colpaert A., Ghislain T.S., Mathius M. \& Bruggeman, A. (2007) - Fluid migration and fluid seepage in the Connemara Field, Porcupine Basin interpreted from industrial $3 D$ seismic and well data combined with high resolution site survey data. Int. J. Earth. Sc., 96, 185-197.

WARNER M. (1990) - Absolute reflection coefficients from deep seismic reflections. Tectonophysics, 173, 15-23.

Whiticar M.J., Faber E. \& Schoell M. (1986) - Biogenic methane formation in marine and freshwater environments: $\mathrm{CO} 2$ reduction vs. acetate fermentation-isotope evidence. Geochim. Cosmochim. Ac., 50, 693-709.

Whiticar M. (1999) - Carbon and hydrogen isotope systematics of bacterial formation and oxidation of methane. Chem. Geol., 161 291-314.

Zecchin M., Tosi L. \& Caffau M. (2011) - Relationship between peat bed formation and climate changes during the last glacial in the Venice area. Sediment. Geol., 238, 172-180.

Zecchin M., Donda F. \& Forlin E. (2017) - Genesis of the Northern Adriatic Sea (Northern Italy) since early Pliocene. Mar. Petrol. Geol., 79, 108-130.

Zhang Y. \& Zhai W-D. (2015) - Shallow-ocean methane leakage and degassing to the atmosphere: triggered by offshore oil-gas and methane hydrate explorations. Front. Mar. Sci, 2, 34, doi: 10.3389/ fmars.2015.00034. 